\title{
Experimental Study on Anti-inflammation and Decreasing Pain Effects of Extracts of Periplaneta Americana
}

\author{
Xiaoqin Xiao \\ Department of Pathogenic Biology, College of Xiangya Basic Medicine \\ Central South University, Changsha 410078, China \\ Shaoyang Medical College, Shaoyang 422000, China \\ E-mail: xiaoxiaoqin@hnsyyz.cn \\ Shiping Wang \\ Department of Pathogenic Biology, College of Xiangya Basic Medicine \\ Central South University, Changsha 410078, China \\ Chen Luo \\ Shaoyang Medical College, Shaoyang 422000, China \\ Xueqin Liu \\ Department of Pathogenic Biology, College of Xiangya Basic Medicine \\ Central South University, Changsha 410078, China
}

\begin{abstract}
To investigate the effects of extracts of Periplaneta Americana on anti-inflammation and decreasing pain, inhibitive effects of the extracts were investigated in different inflammatory models, for instance, cotton induced-granuloma tissue proliferous inflammation of mice, egg white induced rat paw edema, stress gastric ulcer of rats, acetic acid induced writhing response of mice, and hot metal board induced-pain of mice. Results showed that extracts of Periplaneta Americana played important roles in anti-inflammation induced by tumefaction, effusion and hyperplasia, and in decreasing pain. There was obviously statistical difference as compared with control group. It can be concluded that extracts of Periplaneta Americana are indeed worthy of further development for potential medicinal value.
\end{abstract}

Keywords: Periplaneta americana, Extracts, Anti-inflammation, Decreasing pain

Periplaneta americana is an insect belonging to Blattidae, Periplaneta. Its medicinal value was firstly recorded in Shen Nong Ben Cao Jing, "it was salty and cold, lived in rivers and swamps, it could cure blood stasis, cold and heat, destroyed accumulation and cured hypopharynx numbness". It was also recorded in Xin Xiu Ben Cao, Ben Cao Gang $\mathrm{Mu}$, etc. Ben Cao Gang $\mathrm{Mu}$ recorded that, firstly, burnt the cockroach dead with boiled water, then dried them by sunshine or roasting, the whole insect could be used as medicine, it had the effect of reliving blood stasis, detoxification and curing malnutrition, inducing diuresis and removing edema, and so on ( $\mathrm{Li}, 2000)$. Modern medical monograph recorded that cockroach had the effects of "promoting blood circulation, removing blood stasis, eliminating accumulation, curing malnutrition, detoxification, diuresis and detumescence", it could be used to cure furuncle, carbuncle and bite of snake and insect (Group of Medicinal Fauna of China, 1983). In this paper, the breeding Periplaneta Americana was used to prepare water extracts, then the extracts' effect of anti-inflammation and decreasing pain were studied in mouse and rat. This study will provide reference for the further study and development of Periplaneta Americana.

\section{Materials and methods}

\subsection{Materials}

\subsubsection{Experimental animals}

Kunming mouse, weight, 20-30 grams, female: male, 1:1; Sprague-Dawley (SD) rat, weight, 180-260 grams, female: male, 1:1. All the animals were provided by Department of Experimental Zoology, College of Xiangya Basic Medicine, Central South University.

\subsubsection{Reagent and medicine}

Nabumetone, Tianjin Smith Kline \&French Laboratorles Ltd; Cimetidine, Hencer Pharmacy, Aspirin, Hunan Xiangyao 
Pharmaceutical co., Ltd.

\subsection{Methods}

\subsubsection{Preparation and dosage of Periplaneta Americana extracts}

The first generation and second generation of adult Periplaneta Americana, coming from pathogenic laboratory of College of Xiangya Basic Medicine, Central South University, were used in the experiment. Adult Periplaneta Americana that were less than one month old were transferred to a separated aquarium, they were fed with water but no food for five to six days to defecate the extrinsic factors of intestine, and then kept at $-20^{\circ} \mathrm{C}$ in refrigerator for $30 \mathrm{~min}$ to be killed. The wing, feet and antenna of Periplaneta Americana were removed and the left part was briefly washed in $75 \%$ ethanol to eliminate the external microbes, after that the Periplaneta Americana was washed with distilled water for three times, and air dried. After weighing the weight, the Periplaneta Americana was put in the mortar in ice bath and whetted for $30 \mathrm{~min}$, and then kept at $-20^{\circ} \mathrm{C}$ for $30 \mathrm{~min}$, the whetting and freezing were repeated for several times until the insects were completely whetted.

Added two volumes 0.02 M PBS (pH 7.4) (Xie, et al., 2003) to the whetted insects and mixed thoroughly, put them at $4^{\circ} \mathrm{C}$ for 6 hours, mixed them at intervals, then centrifuged at $3000 \mathrm{rpm}$ for $30 \mathrm{~min}$, the supernatant was the extracts of Periplaneta Americana, including proteins, polysaccharid and small molecular substances. The dosages of extracts were $125 \mathrm{mg} / \mathrm{kg}$ (low dosage group) and $250 \mathrm{mg} / \mathrm{kg}$ (high dosage group). The dosage of physiological salt is the same as that of medicine.

1.2.2 The influence of extracts on cotton induced-granuloma tissue hyperplasia of mice (Pan, et al., 2003)

40 Kunming mice, each was sterilized on the skin of back, the midline skin was cut with an ophthalmic scissors, and cut was inserted a blunt forceps toward the neck to isolate the skin and the tissue under the skin, resulting in a $1.5 \mathrm{~cm}$ space, then a gobbet of absorbent cotton was put under the skin, and then the cut was sewed. After 24 hours, the mice were separated into 4 groups; one gastric perfusion with extracts, Nabumetone and physiological salt water was done from the mouth every day, totally four times. 24 hours after the last gastric perfusion, mice were killed by breaking the neck. Cut the dorsal skin of the mice, and carefully peel off the granuloma tissue, weighed the wet weight of granuloma and observed the hyperplasia situation of granuloma in each group. Calculated the inhibition rate of the tested substance on granuloma tissue hyperplasia.

\subsubsection{The influence of extracts on egg white induced rat paw edema (Huang, et al., 2004)}

40 Kunming mice were randomly separated into four groups, one gastric perfusion with medicine or physiological salt water was done from the mouth every day, totally four times. $30 \mathrm{~min}$ after the last gastric perfusion, mice were firstly etherized with aether, and then their paws were injected with newly prepared $10 \mathrm{~mL} 10 \%$ egg white. During the injection, the hind leg was put straight, the pinhead was inserted into the tissue under the skin in the middle of paw, part of the egg white was injected upwards, and part of them was injected downwards. The thickness of paw was measured with micrometer calipers at 0 hour after injection and 1 hour after injection (the peak of edema) at the same position. Recorded the time needed to reach the peak and the time for the fade away of peak. The variation of paw thickness compared with that at 0 hour was used to indicate the edema degree. The inhibition rate of tested substance on paw edema was calculated.

\subsubsection{The inhibition of extracts on stress gastric ulcer of rats (Lehmann and Stalder, 1998)}

40 rats were randomly divided into four groups; one gastric perfusion with medicine or physiological salt water was done from the mouth every day, totally four times. Two days after gastric perfusion, rats were fed with water but no food, and kept in a special iron cage to restrict its free movement, or rats could be gently etherized with aether and fixed by binding its four limbs to wire netting to restrict its free movement, then the rat were vertically soaked into $4^{\circ} \mathrm{C}$ water with its head upward, until the water comes to the xiphisternum. After 2 hours, the rats were killed by breaking their necks or decollation. Opened the abdominal cavity, ligated the pylorus and took out the whole stomach, injected $10 \mathrm{~mL}$ $10 \%$ formalin and then soaked the stomach in $10 \%$ formalin to fix the interior and exterior layers of the stomach. Cut the stomach along the greater curvature, washed the content inside the stomach with tap water and spread out the stomach on a glass board, cleaned the blood streak on the stomach lining, observed the damage of stomach lining, measured the length of damaged stomach lining under the anatomical microscope to establish the ulcer index, specifically, if the length of the damaged stomach lining was longer than $1 \mathrm{~mm}$, each millimeter would be 1 point, if the width was longer than $1 \mathrm{~mm}$, it would get double points, and if both the length and width were less than $1 \mathrm{~mm}$, it would get 0.5 point. The total points would be the ulcer index of the rat, and then the ulcer inhibition rate was calculated.

\subsubsection{The influence of extracts on acetic acid induced writhing response of mice (Xu, et al., 1991)}

40 Kunming mice were randomly separated into four groups, one gastric perfusion with medicine or physiological salt water was done from the mouth every day, totally four times. 2 hours after the last gastric perfusion, injected $0.2 \mathrm{~mL}$ $0.6 \%$ acetate acid into the abdominal cavity, observed the writhing response times within 20 min, calculated the 
inhibition rate.

1.2.6 The influence of extracts on hot metal board induced-pain of mice

40 Kunming mice were randomly separated into four groups, firstly numbered the mice, kept the temperature of mental board at $55 \pm 0.5^{\circ} \mathrm{C}$ and the room temperature at $15-18^{\circ} \mathrm{C}$, put the mice on the mental board, observed the time for mice to lick their feet for the first time, and determine the basic pain threshold. Then fed the mice normally, and gave one gastric perfusion with medicine or physiological salt water from the mouth every day, totally four times, tested the pain threshold of mice 1 hour, 2 hours 3 hours and 4 hours after the fourth gastric perfusion, recorded the variation of pain threshold.

\section{Results}

\subsection{The influence of extracts on cotton induced-granuloma tissue hyperplasia of mice}

As shown in table 1 that the extracts of Periplaneta Americana could inhibit the cotton induced-granuloma tissue hyperplasia of mice, it had statistical significance compared with the control $(\mathrm{P}<0.01$ or $\mathrm{P}<0.05)$. The high dosage group showed more obvious effect, indicating that the anti-inflammation effect had positive correlation with dosage of medicine within a certain extent.

\subsection{The influence of extracts on egg white induced rat paw edema}

It can be seen from table 2 that the high dose group and low dose group showed significant inhibition on the egg white induced rat paw edema of mice, inhibition rate were $48.54 \%$ and $54.04 \%$ respectively, which were higher than the inhibition rate of Nabumetone $(45.78 \%)$. And there was significant difference compared with the control group $(\mathrm{P}<0.01)$.

\subsection{The inhibition of extracts on stress gastric ulcer of rats}

As shown in table 3 that the extracts had significant effect to inhibit the stress gastric ulcer of rats, moreover, the inhibition rate had correlation with the concentration of extracts, there was statistic significance compared with the control group $(\mathrm{P}<0.01$ or $\mathrm{P}<0.05)$.

\subsection{The influence of extracts on acetic acid induced writhing response of mice}

After injected with certain amount of acetic acid, the visceral layer and parietal layer of mice would be stimulated, accordingly induce long time phlogistic pain and writhing response, for example, the abdominal wall would sink, the trunk and hind limbs would extend, and the buttocks would rise. Table 4 showed that the extracts of Periplaneta Americana could effectively reduce acetic acid induced pain of mice, the writhing times were significantly reduced, and showed statistical significance $(\mathrm{P}<0.01)$.

\subsection{The influence of extracts on hot metal board induced-pain of mice}

As shown in table 5 that the extracts of Periplaneta Americana could increase the pain threshold of mice, and the effect was the best 2 to 3 hours after taking the medicine. Compared with the basic pain threshold, it had statistical significance, and the effect of decreasing pain was better than that of aspirin.

\section{Discussion}

The anti-inflammation effects and decreasing pain of extracts of Periplaneta americana were studied in animals. Results showed that extracts of Periplaneta americana had the effect of anti-inflammation induced by tumefaction, effusion and hyperplasia, and had the effect of decreasing pain. Preliminary tissue pathological observation also supported the anti-inflammation and decreasing pain effects of extracts of Periplaneta Americana.

The extract of Periplaneta Americana is complex, study shows that it contains protein, polysaccharid, and soluble small molecular substances. Which ingredient functions in the anti-inflammation and decreasing pain is still unclear, but there is no doubt that the Periplaneta Americana is a potential resource for anti-inflammation and decreasing pain medicine, further study should be carried out.

\section{References}

Group of Medicinal Fauna of China. (1983). Medicinal Fauna of China, book II [M]. Tianjin, Tianjin Science \& Technology Publishing House. 93.

Huang, Lei. Wen, Changfan and Li, Jielian. (2004). Experimental studies on effects of Sini Granule with additives on anti-inflammation and immunity [J]. Chinese Journal of Information on Traditional Chinese Medicine. 11 (2). $120-122$.

Lehmann F S and Stalder G A. (1998). Hypotheses on the role of cytokines in peptic ulcer disease [J]. Clin Invest. 28: 511-519.

Li, Shizhen. (2000). Ben Cao Gang Mu [M]. Beijing, People's Medical Publishing House. 1010.

Pan, Jingqiang. Liu, Huichun. Han, Chao et al. (2003). Pharmacological studies of Yinqiaosan Concentrated Tea Bag on 
anti-inflammation, defervescence, acesodyne, bacteriostasis and antivirus [J]. Guangdong Pharmaceutical Journal. 13 (1). 359-366.

Xie, Jiangbi. He, Weiguo. Weng, Ning et al. (2003). Extraction and isolation of the anti-tumor protein components from earthworm (Eisenia fetida andrei) and the anti-tumor activity [J]. Chinese Journal of Biochemistry and Molecular Biology. 19 (3). 359-366.

Xu, Shuyun. Bian, Ruliang and Chen, Xiu. (1991). Methodology of Pharmacological Experiment [M]. Shanghai, Shanghai Science \& Technology Press. 528-535.

Table 1. The influence of extracts of Periplaneta Americana on cotton induced-granuloma tissue hyperplasia of mice

\begin{tabular}{ccccc}
\hline Group & Dose $(\mathrm{mg} / \mathrm{kg})$ & Number of mice & $\begin{array}{c}\text { Granuloma Wet } \\
\text { weight }\end{array}$ & Inhibition rate (\%) \\
\hline $\begin{array}{c}\text { Low dosage } \\
\text { group }\end{array}$ & 125 & 10 & $432.73 \pm 42.13$ & 15.04 \\
$\begin{array}{c}\text { High dosage } \\
\text { group }\end{array}$ & 250 & 10 & $401.21 \pm 35.76$ & 21.22 \\
$\begin{array}{c}\text { Nabumetone } \\
\text { group }\end{array}$ & 250 & 10 & $413.62 \pm 28.83$ & 18.79 \\
$\begin{array}{c}\text { Physiological salt } \\
\text { water group }\end{array}$ & 10 & $509.32 \pm 108.44$ & \\
\hline
\end{tabular}

Table 2. The influence of extracts of Periplaneta Americana on egg white induced rat paw edema

\begin{tabular}{ccccc}
\hline Group & Number of mice & Dose $(\mathrm{mg} / \mathrm{kg})$ & Edema rate $(\mathrm{mm})$ & Inhibition rate (\%) \\
\hline $\begin{array}{c}\text { Low dosage } \\
\text { group }\end{array}$ & 10 & 125 & $8.97 \pm 3.58$ & 48.54 \\
$\begin{array}{c}\text { High dosage } \\
\text { group } \\
\text { Nabumetone } \\
\text { group }\end{array}$ & 10 & 250 & $8.01 \pm 5.69$ & 54.04 \\
$\begin{array}{c}\text { Physiological salt } \\
\text { water group }\end{array}$ & 10 & 250 & $9.45 \pm 2.04$ & 45.78 \\
\hline
\end{tabular}

Table 3. The influence of extracts of Periplaneta Americana on stress gastric ulcer of rats

\begin{tabular}{ccccc}
\hline Group & Number of mice & Dose $(\mathrm{mg} / \mathrm{kg})$ & Ulcer index & Inhibition rate (\%) \\
\hline $\begin{array}{c}\text { Low dosage } \\
\text { group }\end{array}$ & 10 & 125 & $34.5 \pm 3.34$ & 26.91 \\
$\begin{array}{c}\text { High dosage } \\
\text { group }\end{array}$ & 10 & 250 & $26.2 \pm 2.20$ & 44.49 \\
$\begin{array}{c}\text { Cimetidine group } \\
\text { Physiological salt }\end{array}$ & 10 & 250 & $24.8 \pm 2.09$ & 47.46 \\
water group & 10 & & $47.2 \pm 1.61$ & \\
\hline
\end{tabular}


Table 4. The influence of extracts on acetic acid induced writhing response of mice

\begin{tabular}{|c|c|c|c|c|}
\hline Group & Number of mice & Dose $(\mathrm{mg} / \mathrm{kg})$ & $\begin{array}{l}\text { Writhing times in } \\
15 \text { minutes }\end{array}$ & Inhibition rate $(\%)$ \\
\hline $\begin{array}{l}\text { Low dosage } \\
\text { group }\end{array}$ & 10 & 125 & $24.25 \pm 15.53$ & 44.06 \\
\hline $\begin{array}{l}\text { High dosage } \\
\text { group }\end{array}$ & 10 & 250 & $22.52 \pm 11.21$ & 48.05 \\
\hline Aspirin group & 10 & 100 & $21.63 \pm 14.36$ & 50.10 \\
\hline $\begin{array}{l}\text { Physiological salt } \\
\text { water group }\end{array}$ & 10 & & $43.35 \pm 11.34$ & \\
\hline
\end{tabular}

Table 5. The effect of extracts of Periplaneta Americana in decreasing hot metal board induced-pain of mice

\begin{tabular}{|c|c|c|c|c|}
\hline Group & $\begin{array}{c}\text { Low dosage } \\
\text { group }\end{array}$ & $\begin{array}{l}\text { High dosage } \\
\text { group }\end{array}$ & Aspirin group & $\begin{array}{l}\text { Physiological salt } \\
\text { water group }\end{array}$ \\
\hline Dose (mg/kg) & & 250 & 125 & \\
\hline $\begin{array}{l}\text { Basic pain } \\
\text { threshold }\end{array}$ & $17.52 \pm 3.5$ & $18.53 \pm 4.9$ & $17.26 \pm 2.3$ & $18.36 \pm 4.5$ \\
\hline $\begin{array}{l}\text { Pain threshold } \\
\text { after } 1 \text { hour }\end{array}$ & $28.53 \pm 3.9$ & $29.32 \pm 7.4$ & $27.47 \pm 4.1$ & $15.38 \pm 5.6$ \\
\hline $\begin{array}{c}\text { Percent Increased } \\
\qquad(\%)\end{array}$ & 62.8 & 58.2 & 59.2 & \\
\hline $\begin{array}{l}\text { Pain threshold } \\
\text { after } 2 \text { hours }\end{array}$ & $41.56 \pm 2.7$ & $42.54 \pm 2.5$ & $38.68 \pm 6.2$ & $18.33 \pm 5.2$ \\
\hline $\begin{array}{c}\text { Percent Increased } \\
\qquad(\%)\end{array}$ & 137.2 & 129.6 & 124.1 & \\
\hline $\begin{array}{l}\text { Pain threshold } \\
\text { after } 3 \text { hours }\end{array}$ & $43.26 \pm 4.3$ & $45.37 \pm 7.9$ & $42.26 \pm 4.9$ & $19.31 \pm 4.3$ \\
\hline $\begin{array}{c}\text { Percent Increased } \\
\qquad(\%)\end{array}$ & 146.9 & 144.9 & 144.8 & \\
\hline $\begin{array}{l}\text { Pain threshold } \\
\text { after } 4 \text { hours }\end{array}$ & $31.34 \pm 7.3$ & $33.24 \pm 6.8$ & $27.75 \pm 6.7$ & $23.52 \pm 3.7$ \\
\hline $\begin{array}{c}\text { Percent Increased } \\
\qquad(\%)\end{array}$ & 78.9 & 79.4 & 60.8 & \\
\hline
\end{tabular}

